\title{
Yerli popülasyon ve mülteci hasta gruplarında azospermi oranları ve etkileyen faktörler
}

\author{
Azoospermia rates and affecting factors in local population and \\ refugee patient groups
}

Serdar Toksöz®e, Yalçın Kızılkan²®

\section{öz}

AMAÇ: Hastanemize erkek infertilitesi şikayetiyle başvuran yerli popülasyon/mülteci hasta gruplarında saptanan azospermi oranları ve buna etki etmesi olası faktörler değerlendirildi.

GEREÇ ve YÖNTEM: Kliniğimizde Ocak 2017 ile Temmuz 2018 yılla$\mathrm{r}$ arasında erkek infertilitesi nedeniyle başvuran ve azospermi saptanan 626 hasta retrospektif olarak değerlendirildi. Çalışmaya alınan hastalar yerli popülasyon ve mülteciler olarak iki gruba ayrıldı. Mülteciler de kampta yaşayanlar ve kamp dışında yaşayanlar olarak ayrıca değerlendirildi. Hastaların yaş, serum Folikül stimülan hormon, Lüteinizan hormon, total Testosteron düzeyleri, skrotal ultrasonografi sonuçları, varikosel varlığı ve varikoselektomi operasyonu bilgileri değerlendirildi. BULGULAR: Yerli popülasyonda azospermik hasta sayısı \%12,4 (377) iken mültecilerde bu sayı \%17,4 (249) idi. Azospermik hasta sayısı mülteci hasta grubunda yerli popülasyon grubuna göre istatistiksel olarak anlamlı derecede yüksek saptandı $(\mathrm{p}<0,05)$. Kamp dışında ve kampta yaşayan mülteci hasta grupları arasından azospermi açısından sayısal olarak belirgin fark olmasına rağmen bu fark istatistiksel olarak anlamlı değildi. Yerli popülasyon ve mülteci hasta grubunda hormon değerleri, skrotal USG bulguları, varikosel varlığı ve varikoselektomi operasyonu geçirme oranları arasında istatistiksel olarak anlamlı fark izlenmedi.

SONUÇ: Çalışmamızda azospermik hastaların mülteci hasta grubunda yerli popülasyona göre daha fazla oranda görülmesi istatistiksel açıdan anlamlı olduğu görüldü. Mültecilerde bağımsız değişkenlerin benzer olmasına rağmen azospermi oranlarının yüksek olmasının beslenme, barınma ve strese bağlı olduğu düşünüldü.

Anahtar Kelimeler: Erkek infertilitesi, azospermi, mülteciler

\section{Giriș}

İnfertilite, cinsel yönden aktif ve kontrasepsiyon uygulamayan bir çiftin bir yıl içerisinde gebelik elde edememesi durumu olarak tanımlanır (WHO). Çiftlerin yaklaşık \%25’i 1 yıl

${ }^{7}$ Hatay Devlet Hastanesi, Üroloji Bölümü, Hatay, Türkiye

${ }^{2}$ Ankara Numune Eğitim ve Araştırma Hastanesi, Üroloji Bölümü, Ankara, Türkiye

Yazışma Adresi/ Correspondence:

Uzm. Dr. Serdar Toksöz

Zirve Caddesi, Zirve sitesi D32 Ekinci/Hatay 31150 Hatay, Türkiye

Tel. $\quad$ +905059142175

E-mail: serdartoksoz@gmail.com

Geliş/ Received: $\quad 05.11 .2018$

Kabul/ Accepted: $\quad 26.12 .2018$

\section{ABSTRACT}

OBJECTIVE: In this study we aimed to evaluate the rates of azoospermia in the local population/refugee patient groups and parameters that may have an effect who were applied to our hospital with male infertility.

MATERIAL and METHODS: We evaluated 626 patients with male infertility who were diagnosed with azoospermia between January 2017 and July 2018 retrospectively. The patients were divided into two groups as local population and refugees. Refugees were also divided as campers and living outside the camps. Age, serum follicle stimulating hormone, luteinizing hormone, total testosterone levels, scrotal ultrasonography (usg) results, presence of varicocele and varicocelectomy operation were evaluated.

RESULTS: The number of azoospermic patients was $12.4 \%$ (377) in local population, this number was $17.4 \%$ (249) in refugees. The number of azoospermic patients was significantly higher in the refugee patient group compared to the local population group $(\mathrm{p}<0.05)$. Although there was a significant difference in terms of azoospermia among refugee patient groups living outside the camps and in the camps, this difference was not statistically significant. There was no statistically significant difference between the ratio of hormone values, scrotal USG results, varicocele presence and varicocelectomy operation in the native population and refugee patient group.

CONCLUSION: In our study, we found that azoospermic patients were higher than local population in refugee patient group and it was statistically significant. Although the independent variables were similar in the refugees, the high rates of azoospermia were thought to be due to factors such as nutrition, shelter and stress.

Keywords: Male infertility, azoospermia, refugees

içerisinde gebelik elde edememektedirler, bunların da \%15'i infertilite için medikal tedavi arayışında olup, \%5’i istemelerine rağmen çocuksuz kalmaktadırlar. İstemelerine rağmen çocuk sahibi olamayan infertil çiftlerin \%50'sinde erkeğe ait nedenler bulunur. İnfertil erkeklerin \%30'unda infertiliteye yol açacak herhangi bir neden bulunamamaktadır. ${ }^{[1]}$

Azospermi, ejakülatta hiç sperm bulunmaması anlamına gelmektedir. Erkeklerin \%1'inde, infertilite yakınması olanların ise \%10-15'inde azospermi görülmektedir. Azospermi nedenleri arasında inmemiş testis, Klinefelter sendromu, germ hücre aplazisi, varikosel ve idiyopatik nedenler yer almaktadır. İdiyopatik erkek infertilitesi olarak adlandırılan 
duruma psikolojik stres, çevresel kirlenmeye bağlı endokrin bozukluklar, beslenme bozuklukları, oksidatif stres ve genetik bozukluklar gibi çeşitli etmenlerin neden olabileceği düşünülmektedir. İdiyopatik infertilitesi olan erkeklerde, infertiliteye neden olabilecek herhangi bir hastalık öyküsü veya hormonal bozukluk olmamasına rağmen semen analizlerinde bozukluklar bulunmaktadır. $[2,3]$

Araştırmalarda infertil erkeklerin çoğunlukla bastırılmış stres biçimlerine sahip oldukları tespit edilmiştir. İnfertil erkeklerde duygudurum bozuklukları $(\% 9,2)$, majör depresyon $(\% 5,1)$ ve anksiyete bozukluklarının $(\% 4,9)$ belli oranlarda görüldüğü bildirilmiştir. ${ }^{[4,5]}$ Erkeklerde psikolojik durumun sperm parametrelerini etkileyerek infertiliteye sebep olduğu tespit edilmiştir. ${ }^{[4]}$

Stres, seminal plazmanın nitrik oksit içeriğini arttırarak sperm kalitesini düşürmektedir. Öncelikle motilite olmak üzere sayı ve morfoloji parametrelerinin tamamını etkilediği çalışmalarda ortaya konmuştur. ${ }^{[5]}$

Birçok çalışma beslenme alışkanlıklarının, sigara içme ve sosyal davranışların yanı sıra çevresel ortamın sperm sayısını, motilitesini ve morfolojisini etkileyebileceğini göstermektedir. Sigara, radyasyon, ağır metal iyonları, alüminyum, flor, böcek ilaçları, aflatoksin ve organik çözücülerin sperm üzerine zararlı etkileri bilinmektedir. Bu çevresel faktörlerin, spermin özellikle fertilizasyon yeteneğini etkilediği düşünülmektedir. ${ }^{[6]}$

Türkiye dört milyon Suriyeli mülteciye ev sahipliği yapması nedeniyle, birçoğu etkili koruma veya sağlık hizmetlerine erişim sağlayamamaktadır. Özellikle mültecilerin depresyon, anksiyete ve travma sonrası stres bozukluğu gibi çeşitli fiziksel ve zihinsel sağlık problemleri sıklıkla yaşadıkları gözlemlenmiştir. Sosyoekonomik dezavantajdan dolayı beslenme ve barınma imkanları yeterli düzeyde olamaması nedeniyle çevresel kirlilik gibi faktörlere maruziyetleri artmaktadır. Kamp dışında kalanların ağır çalışma koşulları ayrıca beden sağlığını tehdit eden önemli bir faktördür. Diyet, beslenme ve kronik hastalıkların önlenmesi konusunda dünya sağlık örgütü günde en az 400 gram meyve ve sebze alımını tavsiye etmektedir. Spesifik yaşam tarzı faktörlerinin semen kalitesi üzerindeki etkisi besin alımının kalitesi ve miktarının, semen parametrelerini etkilemesi beklenir. Bu bulgular savaş mültecilerine psiko-sosyo-kültürel bütüncül bir yaklaşımın sergilenmesi gerektiği yeterli sağlıklı beslenme ve barınma ihtiyacının karşılanması gerekliliğini ortaya koymaktadır. ${ }^{[7-9]}$ Çalışmamızda hastanemize infertilite şikayetiyle başvuran yerli popülasyon ve mülteci hasta gruplarında saptanan azospermi oranlarını ve etki etmesi muhtemel sebepleri araştırmayı planlandık.

\section{GEREÇ VE YÖNTEM}

Kliniğimizde 1 Ocak 2017 ile 1 Temmuz 2018 yılları arasında erkek infertilitesi nedeniyle başvuran ve spermiyogram sonucunda azospermi saptanan 626 hasta retrospektif olarak değerlendirildi. Çalışmaya alınan hastalar yerli popülasyon ve mülteciler olarak iki gruba ayrıldı. Mülteciler hasta bilgi sistemindeki adres kayıtlarına göre kampta yaşayanlar ve kamp dışında yaşayanlar olarak ayrıca karşılaştırılıp değerlendirildi. Hastalar yaş, Serum Folikül stimülan hormon (FSH), Lüteinizan hormon (LH), Total testosteron, skrotal ultrasonografi (USG) bulguları (varikosel, hipoplazik/atrofik testis) ve varikoselektomi kriterlerine göre analiz edildi. Stres, depresyon, psikolojik travmaya ve düşük beslenme kalitesine sahip mülteci hasta gruplarında azospermi oranlarının yerli popülasyonla farklı olup olmadığını ve varsa bu farkın nedenlerini ortaya koymaya çalıştık.

Hasta bilgi sisteminden elde edilmiş veriler hasta uyruğuna göre karşılaştırıldı. İstatistiksel analizler Statistical Package for Social Sciences v.22 programı kullanılarak yapıldı. Bağımlı hasta grubu değişkeni; bağımsız değişkenler olan yaş, serum FSH, LH, testosteron, bilateral atrofik/ hipoplazik testis, varikosel, varikoselektomi sonuçlarıla karşılaştırıldı. Toplam sekiz adet bağımsız değişken hasta grubu ile ilişkisi ayrı olarak tek değişkenli lojistik regresyon (LR) analizi kullanılarak değerlendirildi. Tüm analizlerde $\mathrm{p}<0,05$ istatistiksel olarak anlamlı kabul edildi.

\section{BULGULAR}

Erkek infertilitesi nedeniyle başvuran 4446 hastanın 3019'u yerli popülasyonken 1427 olgu mültecilerden oluşmakta idi. Mülteci hasta grubunda 1047 kişi kamp dışında yaşarken, 380 kişi çeşitli kamplarda kalmakta idi. Yerli poülasyonda yaş ortalaması 26,4 (19-64) iken mültecilerde 24,8 (17-56) idi. Yerli popülasyonda azospermik hasta sayısı \%12,4 (377) iken mültecilerde bu sayı \%17,4 (249) idi. Azospermik hasta sayısı mülteci hasta grubunda yerli popülasyon grubuna göre istatistiksel olarak anlamlı derecede yüksek saptandı $(\mathrm{p}<0,05)$ (Tablo 1$)$. Mülteci grubunda azospermik hasta sayısı kamp dışında yaşayanlar için \%17,7, kampta yaşayanlar için \%16,5 idi. Kamp içi ve kamp dışında kalan hasta grupları arasında azospermi açısından anlamlı fark saptanmadı. Yerli popülasyon ve mülteci hasta grupları arasından yaş, serum FSH, LH, Testosteron, varikosel varlığı, skrotal USG bulguları ve varikoselektomi operasyonu geçirme oranları arasında istatistiksel olarak anlamlı fark izlenmedi. Yerli ve mülteci hasta gruplarının tanımlayıcı bilgileri Tablo 2'de verilmiştir. 
Tablo 1. Yerli / Mülteci infertil ve azospermik hasta sayıları

\begin{tabular}{lcccc}
\hline Hasta Grupları & $\begin{array}{c}\text { Yerli } \\
\text { Popülasyon }(n)\end{array}$ & $\begin{array}{c}\text { Mülteci } \\
(n)\end{array}$ & $\begin{array}{c}\text { OR } \\
(95 \% \mathrm{Cl})\end{array}$ & $p$ \\
\hline Infertil hasta & 3019 & 1427 & 1.1 & 0,324 \\
& & & $(0.8-3.7)$ & \\
$\begin{array}{l}\text { Azospermik } \\
\text { hasta }\end{array}$ & 377 & 249 & 2.0 & 0,015 \\
\hline
\end{tabular}

Tablo 2. Yerli/Mülteci hasta gruplarının tanımlayıcı bilgileri

\begin{tabular}{|c|c|c|c|}
\hline Değiş̧kenler & $\begin{array}{c}\text { Yerli } \\
\text { (min-maks.) }\end{array}$ & $\begin{array}{c}\text { Mülteci } \\
\text { (min-maks.) }\end{array}$ & $p$ \\
\hline Yaş (ort)(yıl) & $\begin{array}{c}32.1 \\
(20-67)\end{array}$ & $\begin{array}{c}28.9 \\
(17-56)\end{array}$ & 0.991 \\
\hline $\mathrm{FSH}$ (mIU/mL) (ort) & $\begin{array}{c}15.4 \\
(0.1-123)\end{array}$ & $\begin{array}{c}10.5 \\
(0.1-73)\end{array}$ & 0.748 \\
\hline LH (mIU/mL) (ort) & $\begin{array}{c}9.2 \\
(0.1-102)\end{array}$ & $\begin{array}{c}7.9 \\
(0,1-47)\end{array}$ & 0.871 \\
\hline Testosteron (ng/mL) (ort) & $\begin{array}{c}4.03 \\
(0.5-12)\end{array}$ & $\begin{array}{c}5.1 \\
(0,08-17)\end{array}$ & 1.265 \\
\hline Varikosel (n) & 95 & 50 & 0.320 \\
\hline Varikoselektomi (n) & 61 & 27 & 0.574 \\
\hline $\begin{array}{l}\text { Tek taraflı hipoplazik/ } \\
\text { atrofik testis (n) }\end{array}$ & 18 & 8 & 0.160 \\
\hline $\begin{array}{l}\text { Bilateral hipoplazik/atrofik } \\
\text { testis (n) }\end{array}$ & 29 & 21 & 0.181 \\
\hline
\end{tabular}

\section{TARTIȘMA}

Mültecilerle ilgili az sayıda çalışma olması ile birlikte bu çalışmalar daha çok zihin sağlığı, iyilik hali ve sosyo-kültürel adaptasyonla ile ilgili yapılmıştır. Mültecilerin yaşadığı psikolojik travma ve stresin beden sağlı̆̆ı üzerinde etkilerini somut verilerle analiz etmiş çalışma sayısı nadirdir. Biz de çalışmamızda mültecilerin maruz kaldıkları zor yaşam koşulları ve stresin infertilite oranlarına yansımalarını semen analizi üzerinden değerlendirmeye çalıştık. Polikliniğe erkek infertilitesi şikâyetiyle başvuran hastalar arasında azospermi oranı bütün dünyada olduğu gibi Suriye'yi de içeren Ortadoğu ülkeleri araştırmalarında \%10-15 olarak tespit edilmiştir. Türkiye içinde aynı oran aralığı geçerlidir. ${ }^{[8,9]}$ Çalışmamızda azosperminin diğer nedenleri arasında her iki grupta farklılık olmamasına rağmen mülteci hasta grubunda azospermi oranlarının yerli popülasyona göre yüksek saptanması neden olarak dikkatlerimizi mültecilerin psikolojik durumlarına ve maruz kaldıkları çevresel faktörlere çekmektedir. Türkiye'de yaşayan mültecilerin psikolojik durumu ve uyumuyla ilgili Smeekes ve ark.'nın yaptığ çalışmada Suriyeli mülteciler günlük yaşamdaki zorluklara ek olarak, kaygı, depresyon, öfke, korku ve hem ilişkilerini hem de günlük işleyişlerini etkileyen aşırı stres belirtileri bildirmişlerdir. ${ }^{[8,9]}$
Mültecilerin zihinsel sağlığ1 ile ilgili uzun dönemli çalışmaların sistematik bir incelemesinde, en az beşte birinin depresyon, anksiyete bozukluğundan muzdarip olduğunu ve göç öncesi travmatik deneyimlere ve göç sonrası strese daha fazla maruz kalmanın en tutarlı faktörler olduğunu göstermiştir. Her üç bozukluğa bağlı olarak, göç sonrası sosyo-ekonomik durumun zayıf olması özellikle depresyonla ilişkilidir. ${ }^{[1,7]}$

İnfertil erkeklerde psikolojik stresin etkisi ve sonuçları üzerine çok sayıda çalışma vardır. Özellikle spermlerin motilitesini azalttığı ayrıca morfoloji ve sperm sayısınıda olumsuz etkilediği bildirilmiştir. Bhongade ve ark., çalışmalarında stresin testosteron seviyelerini düşürmesine bağlı olarak FSH, LH sevilerinin arttığı ve sperm kalitesinin bozulduğunu ortaya koymuşlardır. ${ }^{[5]}$

Subfertil erkeklerde depresyon ve anksiyetenin, seks hormonu bağlayıcı globülin (SHBG)'nin düşük sekresyonuna ve kortizol/prolaktin daha yüksek sekresyonuna neden olarak etki ettiği bildirilmiştir. Erkek hastalarda depresyon ve anksiyete, semen hacminin ve sperm yoğunluğunun azalmasına neden olmaktadır. ${ }^{[10]}$

Nordkap ve ark., 1215 olguluk çalışmalarında, hasta grubunu anksiyete skor testleri neticesinde düşük orta ve yüksek stres düzeyi olarak üç gruba ayırmıştır ve en düşük sperm kalitesi (\%38), yüksek stres düzeyine sahip grupta, düşük düzeyde stresli grupta ise sperm kalitesindeki düşme daha az (\%15) olarak tespit etmişlerdir. İnfertil erkeklerde, $\% 17$ oranında kaygı ve/veya depresif bozukluk bildirilmiştir. ${ }^{[11]}$

Bártolo ve ark. Portekizde 112 infertil çifti dahil ettikleri çalışmalarında katılımcılar Envanter Durumluk-Sürekli Kaygı Formu Y (STAI-Y), Beck Depresyon Ölçeği-II (BDIII), Çift Uyum Ölçeği (DAS) ve Doğurganlık Problemleri Envanteri (IFP) ile değerlendirilmiştir. Stres altındaki erkeklerin infertilite tedavisine ve yardımcı üreme tekniği tedavisine de uyum sağlamadıklarını çalışmalarında göstermişlerdir. ${ }^{[10]}$

İnfertil erkeklerde semen kalitesini bozduğu tespit edilen bir diğer önemli başlık çevresel faktörlerdir. ${ }^{[12]}$ Hastanın alışkanlıkları, maruz kaldığı çevresel ajanlar ve ağır iş yükünün oligopsermik ve azospermik hastalarda etkisi birçok çalışmada bildirilmiştir. Çalışmamızda mülteci hasta grubunda azospermi oranının yüksek çıkmasında mültecilerin yaşadığı stresin yanı sıra çevresel faktörlerin de etkili olduğunu düşünmekteyiz. Beslenme, barınma ve ağır iş yükü mültecilerin önemli sorunlarını oluşturmakla birlikte kamp dışında kalan hastaların bu sorunlara daha çok maruz kaldıkları bildirilmiştir. ${ }^{[13]}$ 
Sperm hücreleri morfolojik, fonksiyonel ve metabolik açıdan vücuttaki diğer hücrelere göre oldukça farklılık gösterir. Bu nedenle, sperm hücrelerinin stres faktörlerine tepkisi somatik hücrelerden farklı olmaktadır. Defektif sperm sayısındaki artış genetik ve çevresel faktörlere bağlanabilir. Artan çevresel toksinler, elektromanyetik radyasyon ve ksenobiyotiklerin sperm hücreleri üzerine negatif etkisi de ön plana çıkmaktadır. Toksinlerin, kimyasalların ve tarım ilaçlarının sperm konsantrasyonu, hareketliliği ve morfolojisi üzerine olumsuz etkileri literatürde belirtilmiştir. ${ }^{[14,15]}$

Semen parametreleri ile doğurganlığı karşılaştıran çalışmalarda, kalıcı çevresel kirleticilerin üremeyi etkileyen faktörlerden biri olduğu gösterilmiştir. Atık sularda aktif farmakolojik ajanların olmasının sperm Deoksiribonükleik asit (DNA) fragmantasyonunu arttırdığı ve sperm hücre hasarı yapabildiği, kanıtlanmış diğer bir faktördür. Tüm bunlar göz önüne alındığında, birçok çevresel ajanın sperm hücrelerinde defektler meydana getirerek erkek üreme potansiyelini düşürdüğü görülmektedir. ${ }^{\left[{ }^{[0]}\right.}$ Çevresel faktörler sperm hücrelerinin nükleer bütünlüğünü bozarak fertiliteyi etkilemektedir. Aitken ve ark. çalısmalarında, DNA hasarının hem testiküler hem de post-testiküler alanda gerçekleşen kompleks bir mekanizma olduğunu göstermişlerdir. Vitamin alımı, düzenli beslenme, kişisel beslenme ve düzenli uykunun sperm kalitesine katkıda bulunduğu çalışmalarda ortaya konmuştur. ${ }^{[16-18]}$ Mülteci popülasyonun ağır çalışma koşulları, atık suya maruziyet ve yetersiz-dengesiz beslenme vücutta daha yüksek oranda DNA hasarına sebep olan süperoksit radikallerin oluşmasına neden olmaktadır.

Çalışmamızı yaptığımız Hatay ilinde yerli polpülasyonla mülteciler arasında ortak dini, kültürel ve etnik yapı olmasına rağmen azospermik hasta oranının yerli popülasyondan belirgin olarak yüksek olmasının savaşın ve göçün psikolojik travmasının oluşturduğu stres bozukluğuna bağ1 mültecilerin semen analizi sonuçlarını etkilediğini düşünmekteyiz. Hormon değerleri ve klinik özellikleri benzer olan hasta gruplarında çevresel etmenlerinde belirli ölçüde mültecilerde semen kalitesini bozarak azospermi oranlarını yükseltmesi muhtemel sebeplerdendir. Mültecilerde daha öncelikli olmakla birlikte infertilite hastalarında psikiyatri desteğine ihtiyaç duyulduğunu ve bu desteğin tedaviye katkı sağlayabileceğini düşünmekteyiz.

Çalışmamızın eksikliklerinden birisi azospermik hastalarda kromozom analizi ve y kromozom mikrodelesyon tetkik verilerinin-kliniğimizde ancak son dönemde yapıldığından-olmamasıdır. Bir diğer kısıtlama ise mülteci hasta popülasyonundan dil problemi nedeniyle sınırlı derecede fertilite öyküsü alınabilmesidir. Beslenme ve stresin semen üzerine etkilerini değerlendiren çalışmalarda non-obstrüktif ve obstrüktif ayrımı yapılmadığından ayrıca ülkelere göre verilen azospermi oranları total olduğu için çalışmamızda toplam oranları kullandık. Psikolojik ve çevresel etmenlerin azospermi oranını etkilediğini en yalın haliyle gözlemleyebileceğimiz ve raporlayabileceğimiz bir ortamda çalışmakta olup çalışmamızın literatüre katkı sunacağını düşünmekteyiz.

Hakem Değerlendirmesi

Dış bağımsız

Çıkar Çatışması

Yazarlar çıkar ilişkisi olmadığını beyan etmişlerdir.

Finansal Destek

Herhangi bir mali destek alınmamıştır

\section{Peer-review}

Externally peer-reviewed.

Conflict of Interest

No conflict of interest was declared by the authors.

Financial Disclosure

No financial disclosure was received.

\section{REFERANSLAR}

1. Singh A, Koner BC, Ray PC, Prasad S, Jamatia E, Masroor M, Singh VK. Effect of CYP1A1 gene polymorphism and psychological distress on seminal analysis parameters. Reprod Health 2016;13:60. [CrossRef]

2. Kızılkan Y. Non-Obstrüktif Azospermili Hastalarda Mikroskobik Testiküler Sperm Ekstraksiyonu Operasyonu Öncesi Sperm Bulma İhtimalini Etkileyen Parametreler. Uzmanlık tezi, Ankara, 2015.

3. Eskiocak S, Gozen AS, Taskiran A, Kilic AS, Eskiocak M, Gulen S. Effect of psychological stress on the L-arginine-nitric oxide pathway and semen quality. Braz J Med Biol Res 2006;39:581-8. [CrossRef]

4. Abou-Saleh MT, Christodoulou GN. Mental health of refugees: global perspectives. BJPsych Int 2016;13:79-81. [CrossRef]

5. Bhongade MB, Prasad S, Jiloha RC, Ray PC, Mohapatra S, Koner BC. Effect of psychological stress on fertility hormones and seminal quality in male partners of infertile couples. Andrologia 2015;47:336-42. [CrossRef]

6. Wogatzky J, Wirleitner B, Stecher A, Vanderzwalmen P, Neyer A, Spitzer D, et al. The combination matters - distinct impact of lifestyle factors on sperm quality: a study on semen analysis of 1683 patients according to MSOME criteria. Reprod Biol Endocrinol 2012;10:115. [CrossRef]

7. Smeekes A, Verkuyten M, Çelebi E, Acartürk C, Onkun S. Social identity continuity and mental health among Syrian refugees in Turkey. Soc Psychiatry Psychiatr Epidemiol 2017;52:1317-24. [CrossRef]

8. Sijbrandij M, Acarturk C, Bird M, Bryant RA, Burchert S, Carswell K, et al. Strengthening mental health care systems for Syrian refugees in Europe and the Middle East: integrating scalable psychological interventions in eight countries. Eur J Psychotraumatol 2017;8(Suppl 2):1388102. [CrossRef]

9. Wdowiak A, Bień A, Iwanowicz-Palus G, Makara-Studzińska M, Bojar I. Impact of emotional disorders on semen quality in men treated for infertility. Neuro Endocrinol Lett 2017;38:50-8.

10. Bártolo A, Reis S, Monteiro S, Leite R, Montenegro N. Psychological Adjustment of Infertile Men Undergoing Fertility Treatments: an Association with Sperm Parameters. Arch Psychiatr Nurs 2016;30:521-6. [CrossRef] 
11. Nordkap L, Jensen TK, Hansen ÅM, Lassen TH, Bang AK, Joensen UN, et al. Psychological stress and testicular function: a crosssectional study of 1,215 Danish men. Fertil Steril 2016;105:17487.e2. [CrossRef]

12. Alpak G, Unal A, Bulbul F, Sagaltici E, Bez Y, Altindag A, et al. Post-traumatic stress disorder among Syrian refugees in Turkey: a cross-sectional study. Int J Psychiatry Clin Pract 2015;19:45-50. [CrossRef]

13. Pelit ES, Katı B, Akın Y, Yeni E. Çevresel stres faktörlerinin sperm hücreleri üzerine etkisi. Androl Bul 2017;19:61-4. [CrossRef]

14. Esmaeili V, Shahverdi AH, Moghadasian MH, Alizadeh AR. Dietary fatty acids affect semen quality: a review. Andrology 2015;3:450-61. [CrossRef]
15. Braga DPAF, Halpern G, Figueira RCS, Setti AS, Iaconelli A Jr, Borges E Jr. Food intake and social habits in male patients and its relationship to intracytoplasmic sperm. Fertil Steril 2012;97:53-9. [CrossRef]

16. Patel A, Sharma PSVN, Narayan P, Nair BVS, Narayanakurup D, Pai PJ. Distress in Infertile Males in Manipal-India: A Clinic Based Study. J Reprod Infertil 2016;17:213-20.

17. Eskiocak S, Gozen AS, Kilic AS, Molla S. Association between mental stress \& some antioxidant enzymes of seminal plasma. Indian J Med Res 2005;122:491-6.

18. Giwercman A, Bonde JP. Declining male fertility and environmental factors. Endocrinol Metab Clin North Am 1998;27:807-30. [CrossRef] 